\title{
Potential Bacterial Symbion of Sea Urchin As a Multi-Drug Resistant (MDR) Antibacterial Agent Against Staphylococcus aureus and Escherichia Coli Bacteria
}

\author{
Suzana Kristy Satriani Fofied ${ }^{1 *}$, Agus Sabdono ${ }^{2}$ and Diah Permata Wijayanti ${ }^{2}$ \\ ${ }^{1}$ Master Program of Marine Science, Faculty of Fisheries and Marine Sciences, Diponegoro University \\ J. Prof. H. Soedarto, S.H, Tembalang, Semarang, Indonesia 50275 \\ ${ }^{2}$ Department of Marine Sciences Faculty of Fisheries and Marine Sciences, Diponegoro University \\ J. Prof. H. Soedarto, S.H, Tembalang, Semarang, Indonesia 50275 \\ Email: suzan.kristy29@gmail.com
}

\begin{abstract}
Staphylococcus aureus and Escherichia coli are pathogenic bacteria agent of many human diseases. Those bacteria infect in various levels and also been antibiotic resistants. Bacterial resistance has become a serious global problem. The purposes of this study were to isolate and identify the symbiotic bacteria of the Sea Urchin that have an antibacterial activity of the Strain Multi-Drug Resistant (MDR) against Staphylococcus aureus and Escherichia coli. Sea Urchin was taken from Panjang island, Jepara Indonesia at 2-3 $m$ depth. The symbiotic bacteria were isolated from Sea Urchin by using dilution method and spread plate method. Phenotypic characteristics was observed on colony shape, color and texture of growing bacteria. While the streak method was used to purify bacterial symbion. The antibacterial activity test was performed using overlay method. The results showed that 3 out of 37 isolates have antibacterial activity against Staphylococcus aureus and Escherichia coli. The BB.03.35 isolate was selected for molecular identification due to the largest inhibitory zone diameter. The sequence of this bacterium showed 97\% homology and closely related to Pseudoalteromonas flavipulchra.
\end{abstract}

Key words: Staphylococcus aureus; Escherichia coli; Sea urchin; antibacterial

\section{Introduction}

Secondary metabolites are compounds that are synthesized by organisms to maintain their life from any competition with other organisms. Secondary metabolites include the substances with sophisticated and variable chemical structures, synthesized by certain variety of strains of microbial species (Sharma et al., 2014). Marine organisms have evolved biochemical and physiological mechanisms that include the production of bioactive compounds for such purposes as protection, communication, and reproduction against predation, infection and competition (Kamalakkannan, 2015). Class of the animals that has the potential of secondary metabolites are Echinoderm (Aprilia et al., 2012).

Sea Urchin (Echinoderm) is one of fishery products with a high economiclly value. This animal is excessively caught by coastal community. They even collect the eggs for food (Vimono, 2007). Spines owned by sea urchins especially in strain spesies Diadema setosum are used to move and protect itself from the attack of preys. These spines contain poison (Abubakar et al., 2012) stated that the toxin produced by sea urchins, can be utilized medicine, which has the potential to be used as an antibiotic candidate because it contains bioactive compounds. The extract of sea urchin ovary showed antimicrobial activity (Marimuthu et al., 2015).

Antibiotics are the most important tools in medicine, but their efficacy is threatened by the evolution of resistance (Bhandari et al., 2016). Antibiotic holds a very important role in the drug ingredients, especially in overcoming the infectious diseases in Indonesia. Antibiotics are used on diseases caused by bacteria. If a bacterium carry several resistance genes, it is called multidrug resistant (MDR) or, informally, a superbug or super bacterium (Adekunle, 2012). Continuous use of antibiotics without noticing the dosage, will accelerate the process of antibiotic resistance. Most infectious bacteria may become resistant towards some antibiotics (Walewangko et al., 2015).

Infectious diseases which infect and attack humans to date are caused by pathogenic bacteria of Staphylococcus aureus and Escherichia coli. 
Staphylococcus aureus bacteria can cause serious infectious diseases such as septicemia, pneumonia, endocarditis, osteomyelitis, gastroenteritis and abscesses, where its infection levels has increased over the past decade (Setiawati, 2015). Escherichia coli is considered to be a faecal contamination indicator in foods due to its presence in the gut, Staphylococcus aureus cause disease through direct invasion by toxin production and followed by tissue destruction (Onwubiko and Sadiq, 2011; Gundogan and Avci, 2014). Based on that problems, therefore, the purpose of this research is to isolate and identify the symbiotic bacteria of Sea Urchins which have the antibacterial activity of Multi Drug Resistant (MDR) strain towards the bacteria of Staphylococcus aureus and Escherichia coli.

\section{Material and Methods}

Sea Urchins samples were collected from Pulau Panjang, Jepara, April 2017. Other materials used for the analysis are the bacteria of Staphylococcus aureus and Eschericia coli are collection culture from Tropical Marine Biotechnology Laboraroty, Aquadest, Zobell 2216E Media, Nutrient Agar (NA) and Nutrien Broth (NB). The tools used in the research were autoclave, incubator, laminary airflow and UV light, homogenizer, bunsen and Analytical Scales. This research was conducted at Tropical Marine Biotechlonogy Laboratory, Integrated Laboratory, Diponegoro University.

\section{Isolation of symbiotic bacteria on sea urchins}

The isolation of the Sea Urchin's symbiotic bacteria was carried out using the dilution method and spread plate method. The samples of Sea Urchins were destroyed by the use of Scalpel, where its gonad and the contents of the stomach were taken out, then insert the \pm 5 grams into $5 \mathrm{~mL}$ of sterile sea water. The sample of $100 \mu \mathrm{L}$ was collected from the dilution series of $10^{-1}, 10^{-2}, 10^{-3}$, $10^{-4}, 10^{-5}, 10^{-6}$ and were spareted into sterile petri dish which contains Zobell $2216 \mathrm{E}$ media which was subsequently incubated at $26^{\circ} \mathrm{C}$ for 2 days in Incubator. Purification of bacterial colonies was separated by inoculate loop, based on the different colors, textures and shapes of colonies on Zobell 2216E media in petri dishes (Madigan et al., 2000). After the pure isolates were obtained, then it should be stored on a media to make it tilt.

\section{Antibacterial activity}

The antibacterial activity test was performed by using overlay method, and the bacterial isolates were checked for purity and maintained on nutrient agar (Nazim et al., 2014). Every one ose of Sea Urchin symbiotic bacteria are planted on Zobell 2216E marine media and incubated at room temperature for 2 days. The concentration of S.aureus and $E$. coli cultur was adjusted to 0,5 McFarland standards. $1 \mathrm{~mL}$ of the test bacteria are taken and inserted into $100 \mathrm{~mL}$ soft agar. Soft agar that has contained test bacteria are poured into a medium that has been overgrown with the isolates of Sea Urchin symbiotic bacteria, then incubated at room temperature for $1 \times 24$ hours. The active isolates of Sea Urchin symbiotic bacteria are seen with the formation of clear zones around colony.

\section{DNA extraction and PCR amplification}

DNA extraction in bacteria begins by planting microbes in new media then it was incubated for $1 \times 24$ hours. When the microbes have grown, took it sufficiently and add 50-100 $\mu$ l aquabides and $1 \mathrm{ml}$ of $0.5 \%$ saponin in PBS and then incubated overnight at $4{ }^{\circ} \mathrm{C}$. In the next day, Used Chelex 100 for Exctraction DNA from bacteria (Walsh et al., 1991). DNA extract for 165 rRNA gene were amplified by PCR using Universal Primer 27 Forward (5'AGAGTTTGATCMTGGCTCAG-3') and 1492 Reverse (5'TACGGTTAACCTTGTTACGACTT-3'). The PCR Mixture consisted of GoTaq ${ }^{\circledR}(25 \mu \mathrm{L})$, Primer $27 \mathrm{~F}(2$ $\mu \mathrm{L})$, Primer 1492R $(2 \mu \mathrm{L})$, DNA template $(2,5 \mu \mathrm{L})$, and $\mathrm{ddH}_{2} \mathrm{O}(18,5 \mu \mathrm{L})$ (Sabdono, 2007). The PCR Program (Biorad T100) used were: denaturation at $45^{\circ} \mathrm{C}$ for 1 minute, anneling at $53,9^{\circ} \mathrm{C}$ for 1 minute, extention at $72^{\circ} \mathrm{C}$ for 30 second and post cycling at $72^{\circ} \mathrm{C}$ for 7 minute. All these stages was repeated 30 cycles.

The PCR product was analyzed by Agarose 1\% gel electrophoresis and the result showed by UVIDoc (UVITEC Cambridge). DNA sequencing was conducted at $1^{\text {st }}$ Base, Singapura by Genetika Science Corporation. The sequence was inserted to BLAST search program to identify the sequences of any closely related organisms.

\section{Results and Discussion}

The symbiotic bacteria were isolated from Sea Urchin are isolated on Zobell 2216E marine media. Phenotypic characteristics was observed on colony shape, color and texture of growing bacteria. The results of morphological identification are 37 isolates of symbiotic bacteria. The data of antibacterial activity of Sea Urchin symbiotic bacteria and bacterial isolates of sea urchin symbionts was presented in Table 1 and Figure 1.

The antibacterial activity test of Staphylococcus aureus and Escherichia coli was performed using overlay method. 


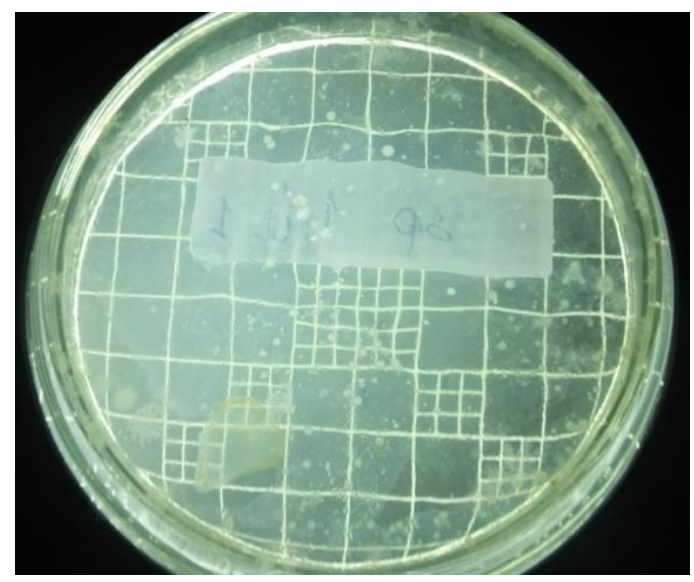

Figure 1. Colonies of Symbiotic Bacteria on Sea Urchins

Table 1. Antibacterial activity On the Symbiotic Bacteria of Sea Urchins against Staphylococcus aureus dan Escherichia coli

\begin{tabular}{|c|c|c|c|c|c|}
\hline \multirow{2}{*}{ Isolate code } & \multicolumn{2}{|c|}{ Bacterial test } & \multirow{2}{*}{ Isolate code } & \multicolumn{2}{|c|}{ Bacterial test } \\
\hline & S. aureus & E. coli & & S. aureus & E. coli \\
\hline BB.01.1 & - & - & BB.02.20 & - & - \\
\hline BB.01.2 & - & - & BB.02.21 & - & - \\
\hline BB.01.3 & - & - & BB.03.22 & - & - \\
\hline BB.01.4 & - & - & BB.03.23 & - & - \\
\hline BB.01.5 & - & - & BB.03.24 & - & - \\
\hline BB.01.6 & - & - & BB.03.25 & - & - \\
\hline BB.01.7 & - & - & BB.03.26 & - & - \\
\hline BB.01.8 & - & - & BB.03.27 & - & - \\
\hline BB.01.9 & - & - & BB.03.28 & - & - \\
\hline BB.01.10 & - & - & BB.03.29 & - & - \\
\hline BB.01.11 & - & - & BB.03.30 & - & - \\
\hline BB.01.12 & - & - & BB.03.31 & - & - \\
\hline BB.02.13 & - & - & BB.03.32 & - & - \\
\hline BB.02.14 & - & - & BB.03.33 & - & - \\
\hline BB.02.15 & + & + & BB.03.34 & - & - \\
\hline BB.02.16 & - & - & BB.03.35 & - & + \\
\hline BB.02.17 & - & + & BB.03.36 & - & - \\
\hline BB.02.18 & - & - & BB.03.37 & - & - \\
\hline BB.02.19 & - & - & BB.02.20 & - & - \\
\hline
\end{tabular}

Description: (+) able to inhibit test bacteria; (-) Unable to inhibit test bacteria

The results in Table 1 and showed, that 3 out of 37 isolates have antibacterial activity against Staphylococcus aureus and Escherichia coli. Isolates BB.02.15 has antibacterial activity against S. aureus and E. coli, while BB.02.17 and BB.03.35 isolates have antibacterial activity against $E$. coli. Antibacterial activity was indicated by the presence of clear zones which present around the isolates. Isolate BB.02.15 were able to inhibit the growth of S. aureus with an inhibition zone diameter of $10.4 \mathrm{~mm}$ and in $E$. coli bacteria, it was capable of inhibiting the growth with an diameter of $10.9 \mathrm{~mm}$. While the BB.02.17 and BB.03.35 isolates were able to inhibit the growth of $E$. coli with the inhibition zone diameter of $21.3 \mathrm{~mm}$ and $27.2 \mathrm{~mm}$, respectively.
Bacterial, protistan, and metazoan symbionts inhabit the lumen of the sea urchin digestive system especially the intestinal region (Holland, 2013).

This is consistent with research done Abubakar et al. (2012) that revealed that the Sea Urchins exhibit antimicrobial activities, particularly the extracts of the guts and gonads. Gonad extract showed the high antibacterial activity against $E$. coli and S. aureus (Akaerina et al., 2015). BB.02.15, BB.02.17 and BB.03.35 Isolates have the ability to inhibit the growth of bacteria test caused by the presence of the active compounds. The clear zone formed around the isolates indicated that there were compounds contained in the isolates. These 


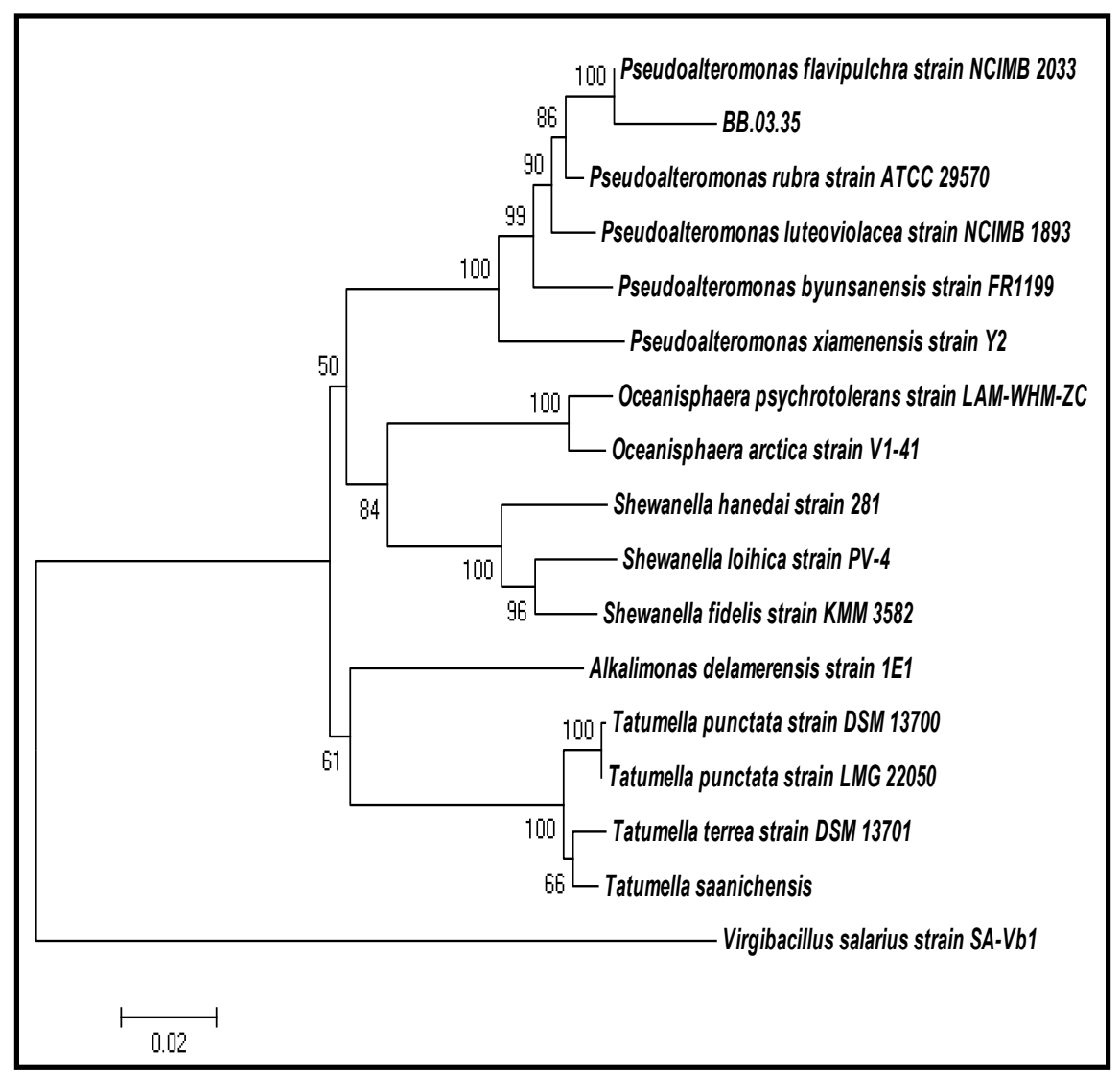

Figure 3. Phylogenetic Tree

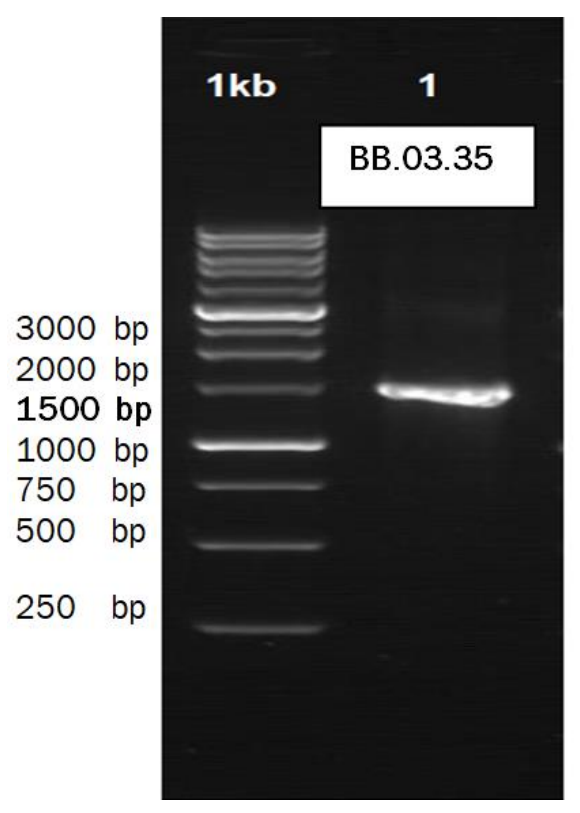

Figure 2. PCR Amplification 16S rDNA Isolate BB.03.35

compounds produced the inhibition of growth in test bacteria. With the visualitation of $16 \mathrm{~S}$ rDNA amplification was presented in Figure 2. Isolate BB.03.35 indicated a best results. Isolate BB.03.35 has a base length of $1500 \mathrm{bp}$. PCR is a scientific technique in molecular biology to amplify a single or a few copies of a piece of DNA across several orders of magnitude, generating thousands to millions of copies of a particular DNA sequence (Joshi and Deshpande, 2010).

Phylogenetic tree are constructed by using MEGA 6 applications. The phylogenetic tree in Figure 3 indicated the bacteria which have the closest genetic relationship with bacterial isolate BB.03.35. BLAST (Basic Local Aligment Search Tool) results showed isolate BB.03.35 have a 97\% homology closely related to Pseudoalteromonas flavipulchra. (Offret et al., 2016) stated the genus Pseudoalteromonas is a Gram-negative, heterotrophic, and aerobic bacteria. Pseudoal-teromonas strain requires a seabed for the growth and association with healthy animals as well as algae (Pelczar, et al., 2000).

\section{Conclusion}

The tree 3 out of 37 isolates have antibacterial activity against Staphylococcus aureus and Escherichia coli. The BB.03.35 isolate was 
selected for molecular identification due to the largest inhibitory zone diameter. The sequence of this bacterium showed $97 \%$ homology and closely related to Pseudoalteromonas flavipulchra. The DNA sequences generated from this study have been registered in GenBank with access numbers LC275180.

\section{Acknowledgement}

Thanks to Lembaga Pengelolaan Dana Pendidikan (LPDP) as the provider of the scholarship therefore the author can complete this research.

\section{References}

Abubakar, L.A., Mwangi, C.M., Uku, J.U. \& Ndirangu, S.N., 2012. Antimicrobial activity of various extracts of the sea urchin Tripneustes gratilla (Echinoidea). African J. Pharmacol. Therapeutics, 1(1): 19-23.

Adekunle, 0.0., 2012. Mechanisms of antimicrobial resistance in bacteria, general approach. Int. J. Pharm. Med. Biol. Sci., 1(2): 166-187. doi: 10.3389/fmicb.2012.00238.

Akerina, F.O., Nurhayati, T. \& Suwandi, R., 2015. Isolation and Characterization of Antibacterial Compounds from Sea Urchin.J. Pengolah. Hasil Perikan. Ind., 18(1): 61-73.

Aprilia, H.A., Pringgenies, D. \& Yudiati, E., 2012. Uji toksisitas ekstrak kloroform cangkang dan duri landak laut (Diadema setosum) terhadap mortalitas nauplius Artemia sp. J. Mar. Res. 1(1): 75-83.

Bhandari, D., Thapa, P., Thapa, K., Tandukar, S. \& Sherchand, J.B., 2016. Antibiotic resistance: Evolution and alternatives. Can. J. Infection Control, 31(3): 149-155

Gundogan, N. \& Avci, E., 2014. Occurrence and antibiotic resistance of Escherichia coli, Staphylococcus aureus and Bacillus cereus in raw milk and dairy products in Turkey. Int. J. Dairy Technol. 67(4): 562-569

Holland, N.D. 2013. Digestive System Chapter 8. Sea Urchin : Biology and Ecology, Editor: John Miller Lawrence. Elsevier B.V. All rights reserved.

Joshi, M. \& Deshpande, J.D., 2010. Polymerase chain reaction: methods, principles and application. Int. J. Biomed. Res. 2(1): 81-97. doi: 10.7439/ijbr.v2i1.83

Kamalakkannan, P., 2015. Marine sponges a good source of bioactive compounds in anticancer agents. Int. J. Pharm. Sci. Rev. Res. 31(2): 132-135.

Madigan, M.T., Martinko, J.M., Parker, J. \& Brock, T.D., 2000. Biology of Microorganisms. Pretice-Hall, New Jersey, USA.

Marimuthu, K., Gunaselvam, P., Aminur, M.R., Xavier, R., Arockiaraj, J., Subramanian, S., Yusoff, F.M. \& Arshad, A., 2015. Antibacterial activity of ovary extract from sea urchin Diadema setosum. Europ. Rev. Med. Pharmacol. Sci. 19(10): 1895-1899.

Nazim, K., Sherwani, S.K., Khan, M.U., Kausar, R. \& Rizvi, G., 2014. Antibacterial Activity of Marine Sponge Collected From Sunhari Beach. FUUAST J. Biol., 4(2): 233-236.

Onwubiko, N.E. \& Sadiq, N.M., 2011. Antibiotic sensitivity pattern of Staphylococcus aureus from clinical isolates in a tertiary health institution in Kano, Northwestern Nigeria. Pan African Med. J. 8(1): 1-7

Offret, C., Desriac, F., Le Chevalier, P., Mounier, J., Jégou, C. \& Fleury, Y., 2016. Spotlight on Antimicrobial metabolites from the marine bacteria Pseudoalteromonas: Chemodiversity and Ecological Significance. Mar. Drugs. 14(7): 129:1-26. doi: 10.3390/md 14070129

Pelczar, M.J. \& Chan, E.C.S. 2008. Basic Microbilogy Chapter 1. Indonesia University. Jakarta. 443 pages.

Sabdono, A. 2007. Biodegradation of Chlorpyrifor by a marine bacterium Bacillus firmus strain BY6 associated with branching coral Acropora sp. J. Coast. Dev. 10(2): 115-123

Setiawati, A. 2015. Increased Culture Resistance of Staphylococcus aureus Bacteria to Amoxicillin Using Adaptive Gradual Method. J. Far. Ind. 7(3): 190-194.

Sharma, A., Kumari, N. \& Menghani, E. 2014. Bioactive Secondary Metabolites: An Overview. Int. J. Sci. Eng. Res. 5(4): 13951407. 
Vimono, I.B. 2007. Overview of Sea Urchin. Oseana. 32(3): 37-46.

Walewangko, G.V.Ch., Bodhi, W. \& Kepel, B.J. 2015. Resistance Test of Escherichia Coli Bacteria Isolated From Dental Plaque Using Mercury And Ampicillin. Jurnal e-Biomedik (eBm). 3(1): 118-124.
Walsh, P.S., Metzger, D.A. \& Higuchi, R., 1991. Chelex 100 as a medium for simple extraction of DNA for PCR-based typing from forensic material. Biotechniques. 10(4): 506-513. 